\title{
Usefulness of Mobile Assisted Language Learning in Primary Education
}

\author{
Kashif Ishaq*,1, Nor Azan Mat Zin ${ }^{2}$, Fadhilah Rosdi ${ }^{3}$ \\ Faculty of Information Science and Technology \\ Universiti Kebangsaan Malaysia \\ Bangi, Malaysia
}

\author{
Adnan $\mathrm{Abid}^{4}$, Qasim $\mathrm{Ali}^{5}$ \\ School of Systems and Technology (SST) \\ University of Management and Technology \\ Lahore, Pakistan
}

\begin{abstract}
Literacy \& Numeracy Drive (LND) is a mobile application that is used in public sector primary schools in Punjab province, Pakistan to teach students of Grade 03 on a tablet for learning languages and Mathematics. Persons designated the role of a Monitoring \& Evaluation Assistant (MEA) visit every school allocated by authorities once in a month and select 07-10 students randomly to evaluate them on his own tablet by asking multiple questions related to English, Urdu and Mathematics. After the evaluation, MEA has to upload the result on the official portal for the respective school. This study aims to evaluate the effectiveness of LND for its usefulness, usability, accessibility, content, and assessments by involving students and teachers using this application in different schools. A mixedmethod study has been adopted in which 57 teachers and nearly 300 students from different locations of the district and from different schools have been selected, to measure the effectiveness of LND and evaluate the effectiveness with the help of interviews and questionnaires. The result reveals, in its current form, the LND application is not effective and needs improvement in usability, design, content, accessibility, infrastructure, and assessment. Furthermore, teachers recommend that game-based learning consists of an interactive interface, phonics, animations. As the more interactive and attractive presentation of the content and variations in the assessment may increase students' involvement and will make this application more effective and will produce good results.
\end{abstract}

Keywords-Literacy and numeracy drive; monitoring and evaluation assistant; assessment; usability; content; design; infrastructure

\section{INTRODUCTION}

"English is not a subject which can be taught; it is a subject which must be learned (Michel West)." English is a world language and is being schooled round the world. It is an efficient method of communication. Native speakers learn it as a primary language and several nations taught this as a second language [7]. English is the language of instruction in schools at all levels [25][2]. Most states have realized the significance of the English language in teaching. Applying modern tools to support students learning English is a critical issue where English is not adopted as a primary language [18]. An important requirement of the day is to learn English as a second language to survive in the global community [8]. It is also observed that having a strong English background supports the candidates for entry into the higher education institutions and assists them to have better job opportunities [16][46].

\section{A. Preliminary Section}

1) Literacy and Numeracy Drive (LND): Outdated procedures of large scale assessment methods for primary students (such as Punjab Education Commission Examinations) are expensive, multifaceted, and irregular. In 2015, the Department of School Education and the Punjab Information Technology Board (PITB) implemented mobilebased application which is low cost named as Literacy and Numeracy Drive (LND) for teaching English, Urdu and Mathematics in all public sector schools of Punjab Province, Pakistan as well as used by Monitoring Officers of School in their scheduled visits of every month in every public school. The application is connected to a widespread question bank and each question is marked with the appropriate student learning results [39]. The main user interface is shown in Figure 1.

To achieve better learning outcomes as it has been mentioned earlier that School Education Department, Punjab has employed LND Application for assessment of learning outcomes of grade three students on a monthly basis. For this purpose, students are educated according to the Prescribed Students Learning Outcomes (SLOs) of three basic subjects on a mobile-based application i.e. English, Urdu and Mathematics [39]. But the major focus of this research is only on the English subject because the English language is a challenge for teachers to teach to the students at all educational levels because it is not their native language and used as a secondary language [60]. Schools in rural areas in Pakistan have no/less access to technology through which they may get help teaching English and they keep on applying conventional teaching methods which only develop cramming and rote learning among students and they remain passive and reluctant to learn English.

2) The Assessment Process of LND: The Monitoring and Evaluation Assistants (MEAs) have been trained to select 7-10 students of grade 3 randomly and to give them the spot test on their own tablet. For the particular grade, theme and key student learning outcome (SLO), MEA ask random questions from established question bank from the randomly selected students to complete the assessment process [78].

*Corresponding Author 


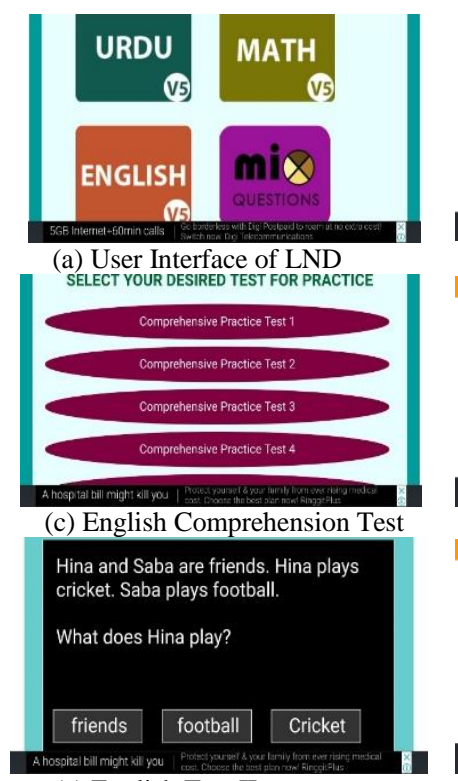

(e) English Test II

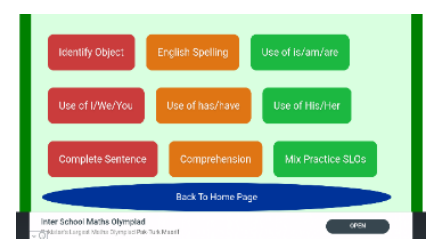

(b) Main dashboard for English

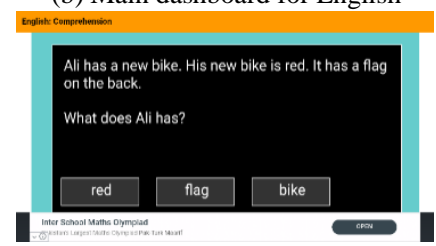

(d) English Test I

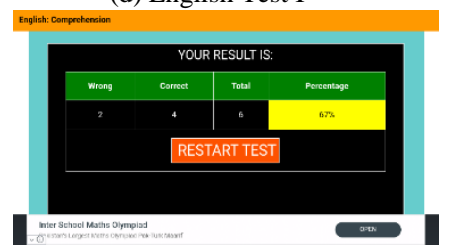

(f) LND Test Assessment
Fig. 1. LND Interfaces.

Across the province of Punjab, there are more than 52000 public sector schools in which this assessment is conducted on a monthly basis by asking 07 questions in total from every student. This process takes less than 05 minutes for each student and approximately 329,000 students are evaluated monthly. According to [53], 6.7 million evaluations have been conducted till now by the MEAs and this data is uploaded on the official portal for the analysis to the educational administrators via SMS and also online dashboard whereas, the monthly assessment result is available for free for every school in every sub-division of all the districts in Punjab province for their information [78][80].

\section{LITERATURE REVIEW AND THEORETICAL FRAMEWORK}

The English language functions like blood in the veins of states worldwide. As a result, the need for the English language has expanded to the level that it involves that citizens of modern societies to be adept enough in order to be successful in their academic and professional careers [20]. A survey conducted by [19] in 89 countries over the globe to identify the qualification and training method for English language teachers to teach English, in which the results revealed that teachers are not specially trained to teach English and it's not the problem of one country or a region but this is the problem in all over the world. The ever-growing need for the English language in different spheres of human life, that's education, financial matters, legislative issues, excitement, innovation, and trade, has made a huge appeal for English language teaching around the world [20].

\section{A. Technology Acceptance}

Davis' (1989) TAM (Technology Acceptation Model) is a well-known model of research in technology admissibility over the past two decades [41][66]. The TAM is developed to describe the predictors of a range of computer knowledge through different people [70], based on a (Fishbein and Ajzen's 1975) principle of rational comportment. The conventional element of TAM [68] is five: perceived utility, ease of use, usage attitudes, shared intention and discrete use. Several researchers have authenticated TAM [50] and TAM can account for approximately $40 \%$ of the device use, according to [69]. Nonetheless, there are a number of aspects that the template has played a crucial role in forecasting its use [34].

That is why the single TAM [81] was updated and the Unification Theory for Technological Entry and Use [51] were also transferred to TAM2 [71]. Extended TAM variants to test the adoption of consumers of a range of learning skills and in various settings including information management systems and smartphone leaning were developed [1].

\section{B. Perceived Ease of use}

The easy use of computer programs in the TAM is an essential determinant of the goal. A simple use is defined by a discreet person as being simple in implementing a process [82] and as having a direct positive effect on the perceived usefulness. Nonetheless, the traditional TAM [22] implicitly affect the purpose of using a method by using behaviors against the use of certain experiments [50][69]. In addition, several studies have not established direct links between userfriendliness and user motivation [47][63][52] claiming to be involved with the work of technology amongst these parameters [63]. [9] suggests that it is hard for the systems to produce any degree of satisfactory disappointment in such places to allow the results of mastering and game technology simple to use [6]. The results of the research [24] can lead to the conclusion that supposed ease of use does not lead to the gratification of digital game students. Nevertheless, [9] found that game preferences are easy to use.

\section{Perceived usefulness}

The use of term performance throughout this interpretation may, however, indicate a focus on the result/result during the application process. In [82] is another important indicator of readiness to make use of the program within TAM. The supposedly "to the stage that one supposes that use of certain devices will enhance their educational outcomes." It may be beneficial in many respects, but the learning process itself might be as important or valuable as the learning outcome. [74] presented external opportunities for growth.

\section{Technology in Education}

Technology is a gift of God and the mother of community formations, expressions, and sciences. It has affected distinctive features of life and re-imagined living. The subject of education has been revolutionized by technology and its importance in schools is being considered. It has worked out to be simpler for teachers to get the learning of personal computers (PC) in teaching. The business of technology in the area of education is four-overlap: it is incorporated as a part of the educational programs, and instructional delivery framework, a method for holding instructions and an apparatus to upgrade the whole learning process [55]. Recently, with the growth of new modernized and net-based advancements students may interface with the web and sign in to explicit sorts of net recreations to take an interest effectively in interactive games [5]. 
Research into the utilization of technology by students is an abandoned area in Pakistan. Most of the researches in Pakistan investigated the utilization of social networking websites by students and educators in teaching and nonteaching settings and the general utilization of the web by tertiary students [57]. The utilization of technology in students' lives has expanded so much that it is needed to show students the method of teaching sentence structure through visuals and motion pictures [12]. Teachers consider the appropriation and usage of Information \& Communication Technology (ICT) in teaching since they are the key to making learning take place [61][30].

\section{E. Teaching English as a Second Language (TESL) in Primary}

In Pakistan, the English language is taught as a second language. Our instructional and official languages are English and Urdu. In Pakistan English is fast using language there are 11\% Pakistani who speak English which makes Pakistan Asian's 3rd largest country [7]. It has its challenges especially in rural area schools because they feel difficulty understanding it because they are bound to learn it as a second language. Rules of English grammar are very difficult for them to understand. They belong to the socio-cultural background where English is not spoken as a primary language. They speak Punjabi at home and Urdu at school whereas English is taught as a secondary language. It is also reported here that difficulties in teaching English are very much related to students' learning [7]. Many factors, parents' socio-cultural background, teacher professional development, curriculum, school infrastructure and facilities contribute to the achievement level of students in English language learning. The only change in the medium of instruction does not make a difference. All related factors need to be addressed in terms of improving English language learning [14].

Globally countries around the world are boosting teachers to use digital resources in language learning because in traditional classrooms teachers and students only communicate in the classroom whereas the learning environment has been changed with the emergence of iPad, iPhone or other Android applications [73]. According to [42] digital technology enables the students to communicate in an environment to enhance motivation in learning a subject. A study conducted by [27] on the use of learning products in the global market for digital English language. They mentioned that its use reached up to $\$ 1.8$ billion in 2013 and it is proposed that revenues would reach over $\$ 3.1$ billion by 2018 . Use of Apps like Duo Lingo is enormously widespread for language learning, with over 70 million sign-ups [17].

\section{F. Mobile-Assisted Language Learning (MALL)}

[67] mentioned that smartphones, mobiles, e-reader, tablets, handheld gaming consoles, portable audio players, laptops, Netbooks and console are effective mobile learning and teaching tools. Mobile Applications for Language Learning (MALL) are delineated as utilization of mobile phones in language teaching and language learning [3][40][79]. The mobile phone enables students to learn casually to improve their learning abilities and language reading [54]. Like western countries, mobile devices are extensively being used in developing countries as well for educational purposes [38][76]. Mobile technology has brought a very positive change in pedagogical approaches. Incorporating mobile devices with the curriculum enables the learners to learn things on an independent level free of time and space by applying the latest software like simulations, learning games, online assessment, language learning applications [31]. A smartphone is used for various kinds of activities like watching movies, social networking, gaming, transfer of remittance, accessing desired information, online admissions and many more [37][3]. 1.2 million Individuals in 2012, exploit mobile applications everywhere throughout the Sphere and in 2017 it is predictable that the amount will be 4.4 million [62]. Mobile learning is a service that gives universal information automatically to the learner and makes the learning content available which helps the success of knowledge [28].

As compared to traditional computer devices, learners are enabled to take the advantages of segmented time to learn without any restriction of time and location with the help of mobile technologies' affordability, movability and userfriendliness [76] because low cost, flexibility, small size, userfriendliness and allowing more sophisticated are the advantages of MALL which are rapidly attracting new users [29]. Likewise, mobile phones can offer language students with understandable info by means of pre-customized programming, offer access to chances of exchange of significance through connecting with the software or instructors, and build a student-focused learning environment [76].

Past research demonstrates that MALL influences vocabulary learning systems, self-governance, and reading comprehension [26]. Similarly, to access new content-ondemand there is a need for Internet access that allows the user to do so whereas it requires the capability for doing such is pointed by [43]. Informal learning may contribute to the habit of personal education and environmental possibilities, including social and technological influences, taking account of the student [72].

On the other side, there may be a question that digital education is not ready to try modern new technology [13]. In App-Store (iOS), Play Store (Android) and other repositories, mobile applications are available. They are rising continuously. Such apps also include strengths and weaknesses in terms of application characteristics, offline functionality, discoverability, speed, deployment, maintenance, and autonomy of networks, limitations to content, approvals method, charges, development costs and user interfaces [11].

Another task involving professional skills and contours is the development of m-learning apps. The progress of learners is either defined by the way that the environment is translated into software or by the system change (not innovation) for the utility of m-learning resources [62]. [72] says that when implementing mobile training, a program programmer is required to follow 10 basic guidelines. Sadly, as a whole, electronic literacy model is an obstacle for both teachers and learners [10], as technological discrimination and behaviors 
are another issues, such as adaptability [65], usability [44], and subscription fee [44], etc.

\section{G. Challenges of English Language Learning in Pakistan}

The education system in Pakistani can be categorized according to the medium of education which corresponds with socioeconomic classes. The education system comprises of government, private, and religious schools (Islamic seminaries named madrasas) where Urdu is most commonly used as intermediate of instruction whereas, in private and elite institutes, English is the medium of instruction [32]. The prime challenge for the English language is multilingual classrooms, facing by the teachers as well as students not only in Quetta, Pakistan but also in other parts of the globe. Due to the different local languages spoken by the students in the classroom, teachers and students have to face a number of problems because it becomes a big challenge for English teachers to deal with students speaking different languages in the classrooms [56].

[33] researched the many challenges facing English language teachers and students in the multilingual schools in District Mianwali and District Bhakkar, Punjab Pakistan. The respondents were teachers and students who revealed, due to the incompetent instructors, educational policy and the test process and lengthy curricula, that college students find it hard to learn English to speak in. The need for language skills in the context of the English curriculum is not recognized at any stage of education in Pakistan, as when students reach the university level they have to face problems with English topics, even if they are adopted as a mandatory topic at the school level. With regard to schools in the public sector, the traditional method for the teaching of English is employed and the government's recommended curriculum is not used to test or teach speaking skills [48]. Language is called an entity, the primary function of which is to facilitate human communication. The development and implementation of the ESP (English Syllabus for Pakistan) mandated that English be used to educate teachers and use communicative/interactive methods [48]. The position of English in Pakistan is especially complex because the government's language, military and higher education are, and even the language of control and the language of the ruling class before independence ruled the country [14].

Some writing skill techniques, such as, brainstorming, outlining and pre-writing discussions on the topic is familiar by some English language teachers but numerous causes that comprise lack of time and learners' weak educational background, restricted curriculum, teacher's lack of command on reading skills and lack of training are considered challenges for teaching reading skills, due to the most of the teacher do not apply these approaches in classrooms. Some of the major encounters faced by instructors in teaching reading skills, students' lack of vocabulary, interest in reading activities and a large classroom [20]. The medium of instruction is English and Urdu in schools but teachers mostly use Gujari and Shina for primary grades which were remarked by the representative of Gujari. In some areas, Gujari is used as a support language for elementary and matric grades as well [14].
There is very poor learning quality throughout the country, especially in public and low-cost private schools. The assessment surveys of students at the national level have shown continued low mastery in science, math, and languages throughout the years. Lower learning results are tied directly to teachers ' low education quality, as the main reasons for teachers in Pakistan are their low level of familiarity and poor pedagogical knowledge. According to [49] Pakistani schools are facing the deficiency of highly qualified subject expert teachers especially in English, Science, and Mathematics through all tertiaries of Pakistan but English as medium of instruction used by the private schools predominantly because children in this sector have strong focus on the use of English language, while students in schools of public sector mostly their regional mother tongue or Urdu as a medium of education. Although, many public sector schools have the medium of instruction in English children are incompetent to accomplish even basic proficiency levels of the language because of the low aptitude of instructors for teaching English as a second language, [49].

By finalizing the literature related to MALL based interactive applications, it is concluded that there is no research has been conducted for the effectiveness of LND in public sector schools for grade 3 student of District Sheikhupura, Punjab, Pakistan and this will be very 1st study on this mobile-based application which is currently adopted by school education department for teaching English, Urdu and Mathematics.

\section{Research Objective:}

- To identify the factors that affect usage of MALL based tool (LND) for TESL in Pakistan.

\section{Research Question:}

- To what extent the teachers in public sector schools have the accessibility of the Internet and smartphones?

- What are teachers' perceptions of LND for its usefulness, content, usability, accessibility, and assessments?

- What are the potential advantages and disadvantages of LND from the students' perspective?

\section{Methodology}

\section{A. Setting and Sample}

This study took place in public sector primary schools of Pakistan which is consisted of four provinces, Punjab, Khyber Pakhtunkhwa, Balochistan, and Sindh. The Punjab province is the most populated area of Pakistan selected for this study which is further divided into 36 districts. It has 52,394 schools (male and female), 12,268,981 students (male and female) and 403,172 teachers (male and female). Furthermore, District Sheikhupura is selected for the survey and interviews of teachers and students which is sub-divided into 05 regions (Ferozwala, Muridke, Safdarabad, Sharaqpur, and Sheikhupura). It has 1,247 schools (male and female) out of which 21 schools were randomly selected to visit in all regions. This study is to measure the effectiveness of LND for English subjects only so, all the teachers in selected schools 
are the subject expert of English, who are using LND mobile application in class for teaching. The sample was drawn from teachers of 21 randomly selected schools out of 1,247 from District Sheikhupura and 57 teachers who were teaching English subjects and also using LND application in class and 300 students of grade 03 only were invited to participate in the study by accomplishing questionnaire and interview in class timing. The rate of response was $100 \%$ because all teachers participated happily.

\section{B. Participants}

For the study, 57 respondents participated from which male respondents were $12(21.1 \%)$ and the majority of respondents were female which was 45 (78.9\%). The age group of $18(31.6 \%)$ participants were $26-30$ which is the majority whereas $09(15.8 \%)$ respondents having the age group of 31-35 whilst $13(22.8 \%)$ and $17(29.8 \%)$ respondents have the age group of $36-40$ and above 40 respectively. From the students' side, 300 participants were selected in which 138 were male which was $46 \%$ and the rest were female with 162 , which corresponds to $54 \%$, out of a total of $100 \%$.

\section{Instrument}

The questionnaire for teachers includes a total of 72 questions and reliability was measured by Cronbach's alpha which was (.805) that indicates a high level of internal consistency. The questionnaire includes nine factors: demographic information, ICT literacy, Design, Usability, Accessibility, Usefulness, Content, Assessment and Provider of application. The questionnaire for students includes a total of 30 questions including demographic information and LND questions and reliability was measured by Cronbach's alpha which was (.865) that indicates a high level of internal consistency.

In the section of demographic information: age, gender, education, and location of the school was asked from the participants whereas in ICT Literacy: access of a computer, mobile devices/tablet and its usage that had yes, no options were asked. In the section of Design of LND: icon of application, attractiveness of screen and buttons, easy to use interface, font size, navigation keys, voice instructions, animations, videos, recommendations of questions, question bank and advertisements; in the section of Usability of LND: easy to find icon, easy to use interface, easy to use touch screen, easy to use input, step by step assistance, difficulty, performance and improvement; in the section of Accessibility: equal access to use the application and equal time for practice; in the section of Usefulness: enhance of vocabulary, saves my time, pictorial presentation, improvement of knowledge, skillful in learning and confident in speaking; in the section of Content: relevancy of content, suitability of content with curriculum, development of interest, suggestion for content and improvement in content; in the section of Assessment: communication of results to parents, suggestions for answers, recommendations of questions on the basis of answers, improving learning outcomes, weakness of the students, and fairness of assessment; in the section of Provider of application: feedback for application, recommendations for application and enforcement of new technology was asked where all items based on 5-point Likert scale, ranging from 1Strongly agree to 5-Strongly disagree.

Lastly, two open-ended questions were asked about missing features in LND and what \& how features should be added in LND to make it interactive, interesting and more useful for students.

\section{Data Collection and Analysis}

The data was gathered during the winter session in 2018 and the questionnaire was administered to all English subject teachers and students of grade 03 and the participation was voluntary and anonymous. For the analysis of questionnaire data, Statistical Package for Social Science (SPSS 25.0) was used in which frequencies were generated for demographic information of the participants whereas descriptive statistics were calculated for the ICT Literacy section. For the sections of LND, Mean and Standard Deviation were calculated accordingly. Response to open-ended questions was analyzed through open coding where first, categories were formed and then the assignment of titles was made.

\section{RESULTS AND DiscUSSIONS}

\section{A. Teachers' Result}

The analysis of the questionnaire in tabular form is given in which higher the mean value shows the strongly disagree and lower the mean value shows the strongly agree.

According to Table 1. majority 18 (31.6\%) respondents having the age group of 26-30 whereas 09 (15.8\%) respondents having the age group of $31-35$ whilst $13(22.8 \%)$ and $17(29.8 \%)$ respondents have the age group of 36-40 and above 40 respectively and According to Table 2 . Out of 57 respondents, male respondents were 12 which is $21.1 \%$ and the majority of respondents were female which was 45 $(78.9 \%)$ of the total of $100 \%$.

According to Table 3 . The majority of the respondents 40 (70.2\%) have their computers at home to use but 17 respondents $(29.8 \%)$ do not have computers to use at their homes for educational or entertainment purposes and according to Table 4. The majority of the respondents 49 $(86.0 \%)$ have their smartphones to use whereas 08 respondents $(14.0 \%)$ do not have smartphones to use in a routine matter for educational or entertainment purposes.

According to Table 5. Which describes that overwhelming majority $53(93.0 \%)$ have Internet access but only $4(07 \%)$ respondents do not have Internet access to use for educational purpose.

TABLE. I. AGE

\begin{tabular}{|l|l|l|}
\hline & Frequency & Percent \\
\hline $26-30$ & 18 & 31.6 \\
\hline $31-35$ & 9 & 15.8 \\
\hline $36-40$ & 13 & 22.8 \\
\hline Above 40 & 17 & 29.8 \\
\hline Total & 57 & 100.0 \\
\hline
\end{tabular}


TABLE. II. GENDER

\begin{tabular}{|l|l|l|}
\hline & Frequency & Percent \\
\hline Male & 12 & 21.1 \\
\hline Female & 45 & 78.9 \\
\hline Total & 57 & 100.0 \\
\hline
\end{tabular}

TABLE. III. DO YOU HAVE A COMPUTER TO USE?

\begin{tabular}{|l|l|l|}
\hline & Frequency & Percent \\
\hline Yes & 40 & 70.2 \\
\hline No & 17 & 29.8 \\
\hline Total & 57 & 100.0 \\
\hline
\end{tabular}

TABLE. IV. DO YOU HAVE A SMARTPHONE?

\begin{tabular}{|l|l|l|}
\hline & Frequency & Percent \\
\hline Yes & 49 & 86.0 \\
\hline No & 8 & 14.0 \\
\hline Total & 57 & 100.0 \\
\hline
\end{tabular}

TABLE. V. DO YOU HAVE INTERNET ACCESS?

\begin{tabular}{|l|l|l|}
\hline & Frequency & Percent \\
\hline Yes & 53 & 93.0 \\
\hline No & 4 & 7.0 \\
\hline Total & 57 & 100.0 \\
\hline
\end{tabular}

1) Design of LND: Participants disagreed with the items related to the design of LND. The majority disagree and strongly disagree with all the statements on this subscale except the item 10 . The majority $(98.2 \%)$ of the participants disagree with the color scheme used in the LND application and the font size is also not readable by $(93.0 \%)$ that create problems while reading the text in LND application. Most importantly, all the participants strongly disagree with $(\bar{X}=$ 1.00 and $S D=.00)$ that the LND application provides voice instructions/animations/videos for learning to the students. These elements can create motivation for the usage of the application. Item 10 received the highest mean score on this subscale (Table 6) in which $(\bar{X}=4.91$ and $S D=.29)$ it clearly states that the LND application shows advertisements while using it in the classroom for teaching or at home while practicing.

2) Usability of LND: The majority of the respondents with item $13(56.1 \%)$ disagree and (43.9\%) strongly disagree, item $17(45.6 \%)$ disagree and (54.4\%) strongly disagree and item $20(98.2 \%)$ strongly disagree where these items have a lowest mean score. These items belong to the easy to use touch screen input, assistance in difficulty and improvement of the application. However, item $18(79.0 \%)$ agree and item 19 (75.4\%) strongly agree and (24.6\%) agree where these items have a highest mean score that explains application difficulty to use and performance of the application is slow (Table 7).
TABLE. VI. MEAN AND STANDARD DEVIATION FOR DESIGN OF LND

\begin{tabular}{|c|l|l|l|l|}
\hline Sr. \# & Items & N & M & SD \\
\hline 1 & $\begin{array}{l}\text { The icons and buttons are attractive } \\
\text { and recognizable. }\end{array}$ & 57 & 1.78 & .57 \\
\hline 2 & $\begin{array}{l}\text { The color scheme of buttons is } \\
\text { attractive. }\end{array}$ & 57 & 1.95 & .23 \\
\hline 3 & $\begin{array}{l}\text { The color scheme of the application } \\
\text { screen is attractive. }\end{array}$ & 57 & 1.56 & .50 \\
\hline 4 & $\begin{array}{l}\text { The font size is easy to read. } \\
\text { The application provides navigation } \\
\text { keys. }\end{array}$ & 57 & 1.95 & .44 \\
\hline 6 & $\begin{array}{l}\text { The application provides useful voice } \\
\text { instructions. }\end{array}$ & 57 & 1.00 & .00 \\
\hline 7 & $\begin{array}{l}\text { The application provides animations } \\
\text { for learning. }\end{array}$ & 57 & 1.00 & .00 \\
\hline 8 & $\begin{array}{l}\text { The application provides videos for } \\
\text { learning. }\end{array}$ & 57 & 1.00 & .00 \\
\hline 9 & $\begin{array}{l}\text { The application instructs to fix the } \\
\text { problem automatically. }\end{array}$ & 57 & 1.16 & .37 \\
\hline 10 & $\begin{array}{l}\text { The application shows too many } \\
\text { advertisements. }\end{array}$ & 57 & 4.91 & .29 \\
\hline 11 & $\begin{array}{l}\text { The application provides a variety of } \\
\text { questions in its question bank. }\end{array}$ & 57 & 1.19 & .40 \\
\hline 12 & $\begin{array}{l}\text { The application provide self- } \\
\text { recommendations for questions. }\end{array}$ & 57 & 1.01 & .13 \\
\hline
\end{tabular}

Note: Scale ranging from 1-Strongly Disagree to 5-Strongly Agree

TABLE. VII. MEAN AND STANDARD DEVIATION FOR USABILITY OF LND

\begin{tabular}{|c|c|c|c|c|}
\hline Sr. \# & Items & $\mathbf{N}$ & $\mathbf{M}$ & SD \\
\hline 13 & The application icon is easy to find. & 57 & 2.44 & 1.09 \\
\hline 14 & $\begin{array}{l}\text { The application interface is easy to } \\
\text { use. }\end{array}$ & 57 & 2.25 & .61 \\
\hline 15 & $\begin{array}{l}\text { The application provides easy to use } \\
\text { touch screen input. }\end{array}$ & 57 & 1.56 & .50 \\
\hline 16 & $\begin{array}{l}\text { The application provides step by } \\
\text { step assistance to use it. }\end{array}$ & 57 & 2.14 & .72 \\
\hline 17 & $\begin{array}{l}\text { The application provides assistance } \\
\text { in difficulty. }\end{array}$ & 57 & 1.46 & .50 \\
\hline 18 & The application is difficult to use. & 57 & 3.77 & .54 \\
\hline 19 & $\begin{array}{l}\text { The performance of application is } \\
\text { slow. }\end{array}$ & 57 & 4.75 & .43 \\
\hline 20 & $\begin{array}{l}\text { The application provider is taking } \\
\text { steps to improve the application. }\end{array}$ & 57 & 1.02 & .13 \\
\hline
\end{tabular}

Note: Scale ranging from 1-Strongly Disagree to 5-Strongly Agree

Respondents are unhappy with the use of LND application because of the various issues like touch screen input, having no step by step assistance to use it. It also does not provide assistance in difficulty as well as it is also difficult to use it. Most important is the performance of application which creates interest for the user to use it smoothly but in item 19, the performance of the application is slow as mentioned $(\bar{X}=$ 4.75 and $S D=.43$ ) that is the problem for the users while using in the class. Lastly, the application provider is not taking any steps to improve the application that affects the smooth usage of the application. 
3) Accessibility of LND: According to Table 8 for Literacy and Numeracy Drive (LND) accessibility, item 21 depicts that the overwhelming majority $(87.7 \%)$ where $(\bar{X}=$ 1.61 and $S D=.82$ ) disagree that each student gets equal access to the application in class. Majority of respondents which is $(96.5 \%)$ where $(\bar{X}=1.63$ and $S D=.70)$ disagree of item 22 that each student gets equal time for the practice of the application in the class because every school is allowed to have only 01 tablets in the huge strength of the class. For the usage of the LND application, it requires proper attention and time to do practice as well as to solve the exam but it is not possible in the situation explained above in the table.

4) Usefulness of LND: In the table 9, approximately all the items showing the lowest mean for the usefulness of the LND application. The application must have some proper output/outcome that could enhance knowledge and vocabulary but the above table shows (96.5\%) respondents disagreed for enhancing vocabulary. It also depicts in item 26 that (96.5\%) majority disagreed that LND application improves there knowledge neither it provides the pictorial presentation of concepts by $(93.0 \%)$ majority in item 25 of table 9 , so the respondents can make an understanding with the text easily and smoothly.

5) Content of LND: According to Table 10 for Literacy and Numeracy Drive (LND) content, the majority of the respondents disagree for the content used in the LND application. This is also depicted in the items given above with the lowest mean score. In item 30, (91.2\%) majority disagreed that the content used in the LND application is taken from the curriculum defined by the Government officials neither it is suitable for learning comprehension of English, disagreed by (95.0\%) majority of item 31. If the content is not suitable for learning, it creates the problems and also the cause of lack of interest for the learner to learn smoothly but item 32 indication, (93.0\%) majority does not interest to learn comprehension using LND application. The last item depicts by an overwhelming majority $(98.2 \%)$ where $(\bar{X}=$ 1.01 and $S D=.13)$ strongly disagreed that the application provider is improving the content problem with the consent of the teacher. If the provider of application uses the content with the consent of teachers and according to the curriculum then it will have more effect on teachers and learners as well.

6) Assessments in LND: The majority of the respondents disagree with the items given in Table 11, in which all the items have the lowest mean for the assessment module. If the application provides the content for learning on the basis of the result of a student then it will be very effective as respondent gets questions or topics to learn for further assessment, but item 37 shows that (86.0\%) majority disagrees that LND application provides topics or questions according to the result of a student. It is also a major element, if an application itself provides the weakness by assessing a respondent automatically according to the given answers then it will create much interest and motivation towards the effective use of it. The majority of the respondents (86.0\%) said the LND application is not providing the weakness of the students in item 39 .

TABLE. VIII. MEAN AND STANDARd DEVIATION FOR ACCESSIBILITy OF LND

\begin{tabular}{|l|l|l|l|l|}
\hline Sr. \# & Items & N & M & SD \\
\hline 21 & $\begin{array}{l}\text { Each student gets equal access to the } \\
\text { application in class. }\end{array}$ & 57 & 1.61 & .82 \\
\hline 22 & $\begin{array}{l}\text { Each student gets equal time for practice } \\
\text { of the application in class. }\end{array}$ & 57 & 1.63 & .70 \\
\hline
\end{tabular}

Note: Scale ranging from 1-Strongly Disagree to 5-Strongly Agree

TABLE. IX. MEAN AND STANDARD DEVIATION FOR USEFULNESS OF LND

\begin{tabular}{|l|l|l|l|l|}
\hline Sr. \# & Items & N & Mean & SD \\
\hline 23 & It helps me to enhance my vocabulary. & 57 & 1.54 & .57 \\
\hline 24 & $\begin{array}{l}\text { It saves my time when I use it for } \\
\text { teaching. }\end{array}$ & 57 & 1.47 & .50 \\
\hline 25 & $\begin{array}{l}\text { The application provides pictorial } \\
\text { presentation of concepts. }\end{array}$ & 57 & 1.07 & .26 \\
\hline 26 & $\begin{array}{l}\text { The application improves my } \\
\text { knowledge. }\end{array}$ & 57 & 1.75 & .51 \\
\hline 27 & $\begin{array}{l}\text { The application makes me skillful in } \\
\text { learning English. }\end{array}$ & 57 & 1.84 & .65 \\
\hline 28 & $\begin{array}{l}\text { The use of application makes me } \\
\text { confident in speaking English? }\end{array}$ & 57 & 1.21 & .41 \\
\hline
\end{tabular}

Note: Scale ranging from 1-Strongly Disagree to 5-Strongly Agree

TABLE. $X . \quad$ MEAN AND STANDARD DEVIATION FOR CONTENT OF LND

\begin{tabular}{|c|l|l|l|l|}
\hline Sr. \# & Items & $\mathbf{N}$ & Mean & SD \\
\hline 29 & $\begin{array}{l}\text { The content in application is relevant } \\
\text { with the course curriculum. }\end{array}$ & 57 & 2.11 & .45 \\
\hline 30 & $\begin{array}{l}\text { The content in application is extracted } \\
\text { from the curriculum. }\end{array}$ & 57 & 1.91 & .58 \\
\hline 31 & $\begin{array}{l}\text { The content in application is suitable for } \\
\text { learning comprehension. }\end{array}$ & 57 & 1.07 & .26 \\
\hline 32 & $\begin{array}{l}\text { The content in application develops the } \\
\text { interest to learn comprehension. }\end{array}$ & 57 & 1.51 & .50 \\
\hline 33 & $\begin{array}{l}\text { The application suggests the content for } \\
\text { learning comprehension. }\end{array}$ & 57 & 1.16 & .37 \\
\hline 34 & $\begin{array}{l}\text { The application provider is improving } \\
\text { content problem with the consent of } \\
\text { teacher. }\end{array}$ & 57 & 1.01 & .13 \\
\hline
\end{tabular}

Note: Scale ranging from 1-Strongly Disagree to 5-Strongly Agree

TABLE. XI. MEAN AND STANDARD DEVIATION FOR ASSESSMENT OF LND

\begin{tabular}{|l|l|l|l|l|}
\hline Sr. \# & Items & N & Mean & SD \\
\hline 35 & $\begin{array}{l}\text { Results in application are } \\
\text { communicated to parents. }\end{array}$ & 57 & 1.89 & .31 \\
\hline 36 & $\begin{array}{l}\text { The application provides suggestions } \\
\text { for answers. }\end{array}$ & 57 & 1.56 & .68 \\
\hline 38 & $\begin{array}{l}\text { The application provides the } \\
\text { recommendations of questions on the } \\
\text { basis of result. }\end{array}$ & 57 & 1.14 & .35 \\
\hline 39 & $\begin{array}{l}\text { Results in application helps in } \\
\text { improving learning outcomes. }\end{array}$ & 57 & 1.28 & .49 \\
\hline 40 & $\begin{array}{l}\text { The application provides the weakness } \\
\text { of students. }\end{array}$ & 57 & 1.25 & .43 \\
\hline
\end{tabular}

Note: Scale ranging from 1-Strongly Disagree to 5-Strongly Agree 
TABLE. XII. MEAN AND STANDARD DEVIATION FOR PROVIDER OF LND APPLICATION

\begin{tabular}{|l|l|l|l|l|}
\hline Sr. \# & Items & $\mathrm{N}$ & Mean & SD \\
\hline 41 & $\begin{array}{l}\text { The application provider asks you about } \\
\text { the feedback of application. }\end{array}$ & 57 & 1.00 & .00 \\
\hline 42 & $\begin{array}{l}\text { The application provider asks you about } \\
\text { the recommendation regarding } \\
\text { application. }\end{array}$ & 57 & 1.00 & .00 \\
\hline 43 & $\begin{array}{l}\text { The application provider enforces new } \\
\text { technology of teaching in schools } \\
\text { without consulting? }\end{array}$ & 57 & 5.00 & .00 \\
\hline
\end{tabular}

Note: Scale ranging from 1-Strongly Disagree to 5-Strongly Agree

7) Support from the Provider: Feedback is the major element that helps to improve the quality of the application or product by getting it from different people. In Table 12, the majority $(100 \%)$ of the respondents strongly disagreed that the provider of LND application asks you about the feedback where $(\bar{X}=1.00$ and $S D=.00)$. The recommendations also have the effect as feedback but in LND, all the respondents $(100 \%)$ where $(\bar{X}=1.00$ and $S D=.00)$ strongly disagreed that the application provider asks the respondents for the recommendations about the LND application improvement. Lastly, all the respondents (100\%) where $(\bar{X}=5.00$ and $S D=$ $.00)$ strongly agrees that the application provider enforces new technology of teaching in schools without the consulting the respondents that have an adverse effect on them.

\section{B. Teachers' Interview}

A face to face interview was conducted in public sector schools in district Sheikhupura, Punjab, Pakistan only with the teachers having specialization in English subject and also have the experience of using mobile and internet. To identify the features/facilities required by teachers (best available) to teach English comprehension effectively, open-ended questions were asked from 45 (78.9\%) female teachers \& 12 (21.1\%) male teachers to improve current LND software used in the school education department in Punjab, Pakistan.

- Animations, Voice Pronunciation and Learning Videos: Out of 45 female respondents, 39 and Out of 12 male respondents, 09 quoted to teach English comprehension will be very much effective with the help of animations, pronunciations of sounds and learning videos because if the students will be given such platform to learn English comprehension with interactive animations and voice pronunciation then they will produce more positive results.

- Design (Colorful Pictures, Icons, and Screens): According to the design perspective, 31 female and 11 male respondents give arguments that if icons and screens will be colorful and well designed, having colorful pictures in their background or pictorial form of presentation of concept will be more effective to develop the interest of students learn more.

- Content (Relevant with Translation and Meaning): For the content perspective, 21 female and 12 male respondents talked about the content of the current LND application that is not relevant to the curriculum and teachers to have to put extra effort to cover the syllabus from the book as well as doing practice on the tablet for LND software. They also said, if the content in the application will be relevant to the curriculum (also have translation and words meaning) then it will more effective for the teacher as well for students to save their time by teaching and learning from a single platform.

- Game-Based (Fun learning with Reading and Spellings): Out of 45 respondents, 21 female and 11 male respondents talked about game-based learning (fun learning) that if we teach students in the environment where they can learn by playing games then it will be much interesting for them to put more attention on learning by playing game as well as they will perform well in reading and spellings.

- Assessment (Focus for outcomes on result basis and communicated to parents): For the assessments, 12 female and 12 male respondents give their views about assessment that result must be communicated to parents to know the performance of their children through SMS service to their mobiles after every test session. Currently, there is no setup is available to analyze the results for the whole class / for one student to keep the record individually to focus on the performance to take steps for the improvement accordingly if required.

- Infrastructure (LED and Multimedia): The current infrastructure is not sufficient to teach the huge strength of class effectively stated by 39 female and 10 male respondents because Government of Province Punjab allowed only one (01) tablet for grade three (03) students in single school where teacher have to use it by taking from the head of the school and after due time, return back to the head of the school. It will be more effective for the whole class as well as teachers to use the big screen like LED or Multimedia to teach students the English language through the game / some interactive platform at the same time because currently, teacher has to call a student one by one manually to teach the English language on the tablet.

\section{Students' Results}

The findings collected under the SPSS (version 25.0) and provided in the form of a table and also represented after the students at public sector schools in Punjab were circulated by some teachers to their students to help address the questionnaire. Students ' demographic data indicates that the age of the respondents was only $06(02 \%)$ in the $05-07$ group, while the majority of the respondents were $217(72.3 \%)$ in the 08-10 age group. 76 (25.3 percent), and finally only 01 (0.3 percent) in the age group of 11-13, belong to the age group of above 13. Of the 300 male participants, 138 were male which was $46 \%$ and the rest were female with 162 , which corresponds to $54 \%$, out of a total of $100 \%$. Only 18 people who responded to the availability of ICT at home have their tablets at home, whereas the majority of respondents have 227 (75.9\%) simple mobile phones at home, but $186(62,2 \%)$ of respondents have smartphones at home for games and 
educational use. Only 16 (5.4 percent) and 100 (33.4 percent) interviewees have laptops and computers at home for games, cartoons or educational activities. In order to make ICT equipment open in class, $100 \%$ of respondents have tablets and computers for schooling, because the Punjab government has 01 tablets and 16 computers available in all public schools throughout the province, whereas the software is available for 9 th and 10th-grade students only to teach guided reading.

In Table 13139 (46.3 percent) respondents have, while 161 (53.7 percent) respondents do not have access to smartphones at home to play games and watch cartoons, knowing the frequency and proportion of the smartphones that they used to play games only, 138 (46.0 percent) of those surveyed, while 162 (54.0 percent) participants did not respond.

According to Table 14, Item 1 explains how LND software can be mastered only by 62 (20.7 percent) interviewees but the remainder of those respondents do not feel LND software is appropriate for English education because the overwhelming majority 283 (94.3 percent) of interviewees find LND software to be not useful since there is no integrated display and colors scheme while the main problem is the language used in the LND app which is not suitable according to 283 (94.3 percent) respondents, 280 of them (93.3 percent) answered that they cannot easily learn English using an LND application. Items 8 and 9 describe that vast majority 289 (96.3 percent) said they could not easily learn the comprehension by LND application, but 100.0 percent agreed that LND applications did not automatically give any content to learn comprehension and that 99.0 percent of the majority did not want to learn comprehension because of this.

In Table 15 (Point 11) it is defined that 100 (33.3\%) of those approved, but $200(66.7 \%)$ did not agree with the evaluation tool LND uses since $283(94.3 \%)$ of those reacting to the assessment did not take part in enhancing comprehension of the English language. No application provides information to learn comprehension based on the results answered by $100.0 \%$ but $99.7 \%$ of respondents accepted to show the lack in understanding to the LND application.

Table 16 shows that 116 respondents say the LND application has no on-screen interactivity or buttons that attract respondents to use this application passionately to learn English, while the majority of respondents say 218 (72.7\%) that contents and exercises are not available properly for the practice of English or animated cartoons. Similarly, students prefer the inclusion of pronunciation for better learning. Lastly, according to the students, content related to practicing and testing needs to be improved and enhanced.

TABLE. XIII. SMARTPHONE AND USAGE

\begin{tabular}{|l|l|l|l|l|l|}
\hline \multirow{2}{*}{ Sr.\# } & \multirow{2}{*}{ Item } & \multicolumn{2}{|l|}{ Frequency } & \multicolumn{2}{l|}{ Percent } \\
\cline { 3 - 6 } & & Yes & No & Yes & No \\
\hline 1 & $\begin{array}{l}\text { Do you have an access to a } \\
\text { Smartphone? }\end{array}$ & 139 & 161 & 46.3 & 53.7 \\
\hline 2 & $\begin{array}{l}\text { Do you use smartphone for } \\
\text { playing games only? }\end{array}$ & 138 & 162 & 46.0 & 54.0 \\
\hline
\end{tabular}

TABLE. XIV. USABILITY, EASE OF USE OF LND APPLICATION

\begin{tabular}{|l|l|l|l|l|l|}
\hline \multirow{2}{*}{ Sr. \# } & \multirow{2}{*}{ Items } & \multicolumn{2}{|l|}{ Frequency } & \multicolumn{2}{l|}{ Percent } \\
\cline { 3 - 6 } 3 & Yes & No & Yes & No \\
\hline 4 & $\begin{array}{l}\text { Do you think Literacy, Numeracy } \\
\text { Drive (LND) software is suitable } \\
\text { for you to learn English? }\end{array}$ & 62 & 238 & 20.7 & 79.3 \\
\hline 5 & $\begin{array}{l}\text { Do you think that LND } \\
\text { application is interesting in } \\
\text { learning English? }\end{array}$ & 17 & 283 & 5.7 & 94.3 \\
\hline 6 & $\begin{array}{l}\text { Do you think you can learn } \\
\text { English easily from LND } \\
\text { application? }\end{array}$ & 20 & 280 & 6.7 & 93.3 \\
\hline 7 & $\begin{array}{l}\text { Do you think that content of } \\
\text { English learning is suitable in } \\
\text { LND application? }\end{array}$ & 17 & 283 & 5.7 & 94.3 \\
\hline 8 & $\begin{array}{l}\text { Do you think teacher teaches } \\
\text { English well with the help of } \\
\text { LND application? }\end{array}$ & 156 & 144 & 52.0 & 48.0 \\
\hline 9 & $\begin{array}{l}\text { Do you think you can learn } \\
\text { comprehension easily with the } \\
\text { help of LND application? }\end{array}$ & 11 & 289 & 3.7 & 96.3 \\
\hline $\begin{array}{l}\text { Do you think application } \\
\text { provides you content to learn } \\
\text { comprehension automatically? }\end{array}$ & $\begin{array}{l}\text { Do you think application } \\
\text { develops interest to learn } \\
\text { comprehension? }\end{array}$ & 3 & 297 & 1.0 & 99.0 \\
\hline
\end{tabular}

TABLE. XV. USEFULNESS OF LND

\begin{tabular}{|l|l|l|l|l|l|}
\hline 11 & $\begin{array}{l}\text { Do you think the method of } \\
\text { assessment adopted in LND is } \\
\text { suitable for you? }\end{array}$ & 100 & 200 & 33.3 & 66.7 \\
\hline 12 & $\begin{array}{l}\text { Assessment of LND improve your } \\
\text { English learning? }\end{array}$ & 17 & 283 & 5.7 & 94.3 \\
\hline 13 & $\begin{array}{l}\text { Application provides the content to } \\
\text { learn comprehension on the basis } \\
\text { of results? }\end{array}$ & 0 & 300 & 0.0 & 100.0 \\
\hline 14 & $\begin{array}{l}\text { Application provides you your } \\
\text { weaknesses to learn } \\
\text { comprehension? }\end{array}$ & 1 & 299 & 0.3 & 99.7 \\
\hline
\end{tabular}

TABLE. XVI. FEATURES FOR IMPROVEMENT IN LND

\begin{tabular}{|c|l|l|l|}
\hline \multicolumn{2}{|l|}{} & Responses & $\begin{array}{l}\text { Percent } \\
\text { of } \\
\text { Cases }\end{array}$ \\
\cline { 3 - 3 } 15 & $\begin{array}{l}\text { Do you think Interactive Screen and } \\
\text { Icons are not available in LND } \\
\text { application for you to learn English? }\end{array}$ & 116 & $38.7 \%$ \\
\hline 16 & $\begin{array}{l}\text { Do you think Content and Exercises } \\
\text { are not available in LND application } \\
\text { for you to learn English? }\end{array}$ & 218 & $72.7 \%$ \\
\hline 17 & $\begin{array}{l}\text { Do you think Animated Learning } \\
\text { Cartoons are not available in LND } \\
\text { application for you to learn English? }\end{array}$ & 298 & $99.3 \%$ \\
\hline 18 & $\begin{array}{l}\text { Do you think Voice Pronunciation is } \\
\text { not available in LND application for } \\
\text { you to learn English? }\end{array}$ & 291 & $97.0 \%$ \\
\hline
\end{tabular}




\section{CONCLUSION}

On the basis of result findings of questionnaire and interview, it is confirmed that LND mobile based application is not much efficient to teach students of Grade 03 because several problems identified specifically in English subject 1) Usability: this application is not usable because of its performance, non-availability of assistance, and not easy to use 2) Design: design is non-professional, not interactive color scheme of screens and icons, no proper layout, problem with font size, display of advertisements, no voice instructions, no animations, non-availability of updated questions 3) Content: the content in application is not aligned completely with curriculum, not suitable for teaching English, and application provider is not taking any steps to improve it 4) Accessibility: this application has not equal access and not equal time for every student to practice in due time of class because the of the huge strength of students 5) Infrastructure: the Government of Punjab allowed only 01 tablets for every school to use LND on it for teaching to grade 3 students which is not possible in huge strength of class with limited time of lecture, Finally 6) Assessment: the method of assessment is not suitable and the results are not communicated to parents as well as the results in LND does not show the status of class as a whole. No improvements are made on the basis or results because teachers have to cover up the syllabus of the book along with the practice of LND in 01 session of class.

\section{RECOMMENDATIONS}

After conducting surveys and interviews from teachers and students to see the usefulness of LND in schools to teach students of grade 03, several problems were identified and the teacher also recommended some improvement for mobilebased LND applications to overcome all the issues.

- Game-Based learning should be adopted for improvement of user experience and the game's challenge must not have the issue of usability as it is necessary to keep the focus on usability while designing a game-based learning application. These points have also been highlighted by [21][23][58].

- The interface design should be attractive in game-based learning application that will have good impact [64] and encouraging the reading by playing games mentioned by [35] because many research studies illustrate that presentation of learning material through video games and animations inspire the students to gain cognitive skills and to improve comprehension. This is also mentioned by [15] in their study.

- The designers must be keeping in mind factors: usefulness, ease of use and clarity of goal that inspired the learners for using games to get the results better for effectiveness and encouraging behavior from learners by participating in such learning activities. These factors also highlighted in [59][73].

- Game-based learning should have music and pronunciation of words which helps the player to develop the motivation and also with the addition of feedback feature to improve the learning capability through a tactile observation of substances. This point is highlighted by [4].

- The game-based learning application should have targeted content because it could help more for the different context of learners and academics can achieve success than those who are failing to do so which is also mentioned by [36].

- The game-based learning must have fair assessment to measure the learning growth and also to keep track the gameplay because progress provides immediate feedback for teachers for their teaching objective and content which also described by [45] and [77] as well as surprises in the game that could be reason of inspiration for effective use of game also mentioned by [75].

\section{ACKNOWLEDGMENT}

This study is funded by the Universiti Kebangsaan Malaysia (The National University of Malaysia), Bangi, Selangor, Malaysia.

\section{REFERENCES}

[1] Abdullah, F., \& Ward, R. (2016). Developing a General Extended Technology Acceptance Model for E-Learning (GETAMEL) by analysing commonly used external factors. Computers in Human Behavior, 56, 238-256.

[2] Abubakar Muhammad, H. (2018). Teaching and Learning English Language in Nigerian Schools: Importance and Challenges. Teacher Education and Curriculum Studies, 3(1), 10. https://Doi.Org/ 10.11648/J.Tecs.20180301.13

[3] Ali, M. M., Malik, N. A., \& Rehman, A. (2016). Mobile Assisted Language Learning (Mall) An Emerging Technology In English Language Class Rooms Of Lahore (Pakistan). Science International, 28(2), 9 .

[4] Arnab, S., Petridis, P., Dunwell, I., \& de Freitas, S. (2011). Enhancing learning in distributed virtual worlds through touch: a browser-based architecture for haptic interaction. In Serious Games and Edutainment Applications (pp. 149-167). Springer, London.

[5] Ashraf, H., Motlagh, F. G., \& Salami, M. (2014). The Impact of Online Games on Learning English Vocabulary by Iranian (Low-intermediate) EFL Learners. Procedia - Social and Behavioral Sciences, 98, 286-291. https://doi.org/10.1016/j.sbspro.2014.03.418

[6] Bass, B. M., \& Riggio, R. E. (2006). Transformational leadership. Psychology press.

[7] Behraam, S. (2015). Difficulties of Teaching English at Primary Level in Rural Areas of Pakistan, 02(04), 3.

[8] Bonilla Medina, S. X., \& Cruz Arcila, F. (2013). Sociocultural factors involved in the teaching of English as foreign language in rural areas of Colombia: An analysis of the impact on teachers' professional development. Research in Teacher Education, 3(2), 28-33.

[9] Boyle, E. A., Hainey, T., Connolly, T. M., Gray, G., Earp, J., Ott, M. \& Pereira, J. (2016). An update to the systematic literature review of empirical evidence of the impacts and outcomes of computer games and serious games. Computers \& Education, 94, 178-192.

[10] Brown,T. H., Mbati, L. S. (2015). Mobile learning: Moving past the myths and embracing the opportunities. International Review of Research in Open and Distributed Learning, 16(2), 115-135.

[11] Budiu, R. (2016, January 19). Mobile: Native Apps, Web Apps, and Hybrid Apps. Retrieved March 28, 2019, from https://www.nngroup. com/articles/mobile-native-apps/

[12] Cakir, I. (2006). The use of video as an audio-visual material in foreign language teaching classroom. Turkish Online Journal of Educational Technology-TOJET, 5(4), 67-72. 
[13] Ching,K. Gwo,J. Chih,C. (2013). A personalized recommendation-based mobile learning approach to improving the reading performance of EFL students. Elsevier, Computers \& Education, 53: 327-336.

[14] Coleman, H., \& Capstick, A. (2012). Language in education in Pakistan: Recommendations for policy and practice. Islamabad: British Council.

[15] Conolly, T., Stansfield, M., Boyle, L. (2009): Games-Based Learning Advancements for Multy-Sensory Human Computer Interfaces: Techniques and Effective Practices. IGI Global Publishing.

[16] Crystal, D. (2012). English as a global language. Cambridge university press.

[17] Duolingo AI Research. (n.d.). Retrieved December 13, 2019, from https://ai.duolingo.com/.

[18] Elaish, M. M., Shuib, L., Abdul Ghani, N., Yadegaridehkordi, E., \& Alaa, M. (2017). Mobile Learning for English Language Acquisition: Taxonomy, Challenges, and Recommendations. IEEE Access, 5, 1903319047. https://doi.org/10.1109/ACCESS.2017.2749541.

[19] Emery, H. (2012). A global study of primary English teachers' qualifications, training and career development. 37.

[20] Fareed, D. M., Jawed, S., \& Awan, S. (2018). Teaching English Language at SSC Level in Private Non-Elite Schools in Pakistan: Practices and Problems. Journal of Education and Educational Development, 5(1), 80. https://doi.org/10.22555/joeed.v5i1.1756.

[21] Gabriel, P., Hirashima, T., \& Yusuke, H. (2018). A Serious Game for Improving Inferencing in the Presence of Foreign Language Unknown Words. International Journal of Advanced Computer Science and Applications, 9(2). https://doi.org/10.14569/IJACSA.2018.090202

[22] Gefen, D., Karahanna, E., \& Straub, D. W. (2003). Trust and TAM in online shopping: an integrated model. MIS quarterly, 27(1), 51-90.

[23] Giessen, H. W. (2015). Serious Games Effects: An Overview. Procedia Social and Behavioral Sciences, 174, 2240-2244. https://doi.org/ 10.1016/j.sbspro.2015.01.881

[24] Hamari, J., \& Keronen, L. (2017). Why do people play games? A metaanalysis. International Journal of Information Management, 37(3), 125141.

[25] Harper, C., \& De Jong, E. (2004). Misconceptions about teaching English- language learners. Journal of adolescent \& adult literacy, 48(2), 152-162.

[26] Hazaea, A. N., \& Alzubi, A. A. (2018). Impact of Mobile Assisted Language Learning on Learner Autonomy in EFL Reading Context. Journal of Language and Education, 4(2), 48-58. https://doi.org/ 10.17323/2411-7390-2018-4-2-48-58

[27] Heil, C. R., Wu, J. S., Lee, J. J., \& Schmidt, T. (2016). A review of mobile language learning applications: Trends, challenges, and opportunities. The EuroCALL Review, 24(2), 32-50.

[28] Hidayat, A., \& Utomo, V. G. (2014). Open Source Based M-Learning Application for Supporting Distance Learning. Telkomnika, 12(3), 657.

[29] Huang, L-L., \& Lin, C-C. (2011). EFL learners' reading on mobile phones. The JALT CALL Journal, 7(1), 61-78.

[30] Hussain, M. A., Niwaz, A., Zaman, A., Dahar, M. A., \& Akhtar, M. S. (2010). Technology Based Learning Environment and Student Achievement in English as a Foreign Language in Pakistan. International Journal of Academic Research, 2(5).

[31] Ismail, H., Harous, S., \& Belkhouche, B. (2016). A Comparative Analysis of Machine Learning Classifiers for Twitter Sentiment Analysis. Research in Computing Science, 110, 71-83.

[32] Karamouzian, F. M., Narcy-Combes, M.-F., \& Ahmed, F. (2014). A Post-Use Evaluation of Pakistani Secondary School English Textbooks. 9(1), 24

[33] Khan, T. J., \& Khan, N. (2016). Obstacles in learning English as a second language among intermediate students of districts Mianwali and Bhakkar, Pakistan. Open Journal of Social Sciences, 4(02), 154.

[34] King, W. R., \& He, J. (2006). A meta-analysis of the technology acceptance model. Information \& management, 43(6), 740-755.

[35] Laamarti, F., Eid, M., \& El Saddik, A. (2014). An Overview of Serious Games. International Journal of Computer Games Technology, 2014, 115. https://doi.org/10.1155/2014/358152
[36] Lameras, P., Arnab, S., Dunwell, I., Stewart, C., Clarke, S., \& Petridis, P. (2017). Essential features of serious games design in higher education: Linking learning attributes to game mechanics. British journal of educational technology, 48(4), 972-994.

[37] Ley, B., Ogonowski, C., Hess, J., Reichling, T., Wan, L., \& Wulf, V. (2014). Impacts of new technologies on media usage and social behaviour in domestic environments. Behaviour \& Information Technology, 33(8), 815-828.

[38] Lim, C. K., Eng, L. S., Mohamed, A. R., \& Mohamed Ismail, S. A. M. (2018). Relooking at the ESL Reading Comprehension Assessment for Malaysian Primary Schools. English Language Teaching, 11(7), 146. https://doi.org/10.5539/elt.v11n7p146

[39] Literacy \& Numeracy. (2019). https://open.punjab.gov.pk/lnd/reports/ open_slo_charts, Retrieved on December 24, 2019.

[40] Liu, M., Navarrete, C., Maradiegue, E., \& Wivagg, J. (2014). Mobile learning and English language learners: A case study of using iPod touch as a teaching and learning tool. Journal of Interactive Learning Research, 25(3), 373-403.

[41] Marangunić, N., \& Granić, A. (2015). Technology acceptance model: a literature review from 1986 to 2013. Universal Access in the Information Society, 14(1), 81-95.

[42] Mchucha, I. R., Ismail, Z. I., \& Tibok, R. P. Developing a GamificationBased Thesaurus App to Improve English Language Vocabulary: A Case study of Undergraduate Students in Malaysia. CARNIVAL ON eLEARNING (IUCEL) 2017, 43.

[43] McQuiggan, S., McQuiggan, J., Sabourin, J., \& Kosturko, L. (2015). Mobile learning: A handbook for developers, educators, and learners. John Wiley \& Sons.

[44] Miangah, T. M. (2012). Mobile-Assisted Language Learning. International Journal of Distributed and Parallel Systems, 3(1), 309-319. https://doi.org/10.5121/ijdps.2012.3126

[45] Minović, M., Milovanović, M., Šošević, U., \& González, M. Á. C. (2015). Visualisation of student learning model in serious games. Computers in Human Behavior, 47, 98-107.

[46] Mohammad, N., Masum, R., Ali, Z., \& Baksh, K. (2017). Teaching Practices of English Language in the Schools of Lasbela District, Pakistan. Case Studies, 6.

[47] Moon, J. W., \& Kim, Y. G. (2001). Extending the TAM for a WorldWide-Web context. Information \& management, 38(4), 217-230.

[48] Naheed, F. (2015). Interactive Approach in English Language Learning and Its Impact on Developing Language Skills. The Dialogue, (1), 9.

[49] National Education Policy Framework. (2018, November). Ministry of Federal Education and Professional Training. Pakistan.

[50] Park, S. Y. (2009). An analysis of the technology acceptance model in understanding university students' behavioral intention to use e-learning. Educational technology \& society, 12(3), 150-162.

[51] Petter, S., DeLone, W., \& McLean, E. (2008). Measuring information systems success: models, dimensions, measures, and interrelationships. European journal of information systems, 17(3), 236-263.

[52] Pituch, K. A., \& Lee, Y. K. (2006). The influence of system characteristics on e-learning use. Computers \& Education, 47(2), 222244.

[53] PMIU. (n.d.). Retrieved December 3, 2019, from https://open. punjab.gov.pk/lnd/reports/district_map

[54] Prensky, M. (2005). What can you learn from a cell phone? Almost anything! Innovate: Journal of Online Education, 1(5).

[55] Raja, R., \& Nagasubramani, P. C. (2018). Impact of modern technology in education. Journal of Applied and Advanced Research, 3(S1), 33. https://doi.org/10.21839/jaar.2018.v3iS1.165

[56] Rasheed, S., Zeeshan, M., \& Zaidi, N. A. (2017). Challenges of Teaching English Language in a Multilingual Setting: An Investigation at Government Girls Secondary Schools of Quetta, Baluchistan, Pakistan. International Journal of English Linguistics, 7(4), 149. https://doi.org/10.5539/ijel.v7n4p149

[57] Rashid, S., Cunningham, U., Watson, K., \& Howard, J. (2018). Revisiting the digital divide(s): Technology-enhanced English language practices at a university in Pakistan. Australian Journal of Applied Linguistics, 1(2), 64-87. https://doi.org/10.29140/ajal.v1n2.7 
[58] S. Deterding, (2015):The lens of intrinsic skill atoms: A method for gameful design, Human-Computer Interaction, vol. 30, no. 3-4, pp. 294-335.

[59] Schell, J. (2019). The Art of Game Design: A book of lenses. AK Peters/CRC Press.

[60] Shamim, F. (2008). Trends, issues and challenges in English language education in Pakistan. Asia Pacific Journal of Education, 28(3), 235249.

[61] Somekh, B. (2008). Factors affecting teachers' pedagogical adoption of ICT. In International handbook of information technology in primary and secondary education (pp. 449-460). Springer, Boston, MA.

[62] Sönmez, A., Göçmez, L., Uygun, D., \& Ataizi, M. (2018). A review of Current Studies of Mobile Learning. Journal of Educational Technology and Online Learning, 1(1), 12-27. https://doi.org/10.31681/jetol.378241

[63] Sun, H., \& Zhang, P. (2006). The role of moderating factors in user technology acceptance. International journal of human-computer studies, 64(2), 53-78.

[64] The Foreign Language Center, Feng-Chia University, Taiwan, \& Wang, B.-T. (2017). Designing Mobile Apps for English Vocabulary Learning. International Journal of Information and Education Technology, 7(4), 279-283. https://doi.org/10.18178/ijiet.2017.7.4.881

[65] Turan, B., Haşit, G. (2014). Teknoloji kabul modeli ve sınıf ögretmenleri üzerinde bir uygulama. Journal of Alanya Faculty of Business, 6 (1), 109-119.

[66] Turner, M., Kitchenham, B., Brereton, P., Charters, S., \& Budgen, D. (2010). Does the technology acceptance model predict actual use? A systematic literature review. Information and software technology, 52(5), 463-479.

[67] UNESCO. (2003). Technology Education Guide. 153.

[68] Venkatesh, V. (2000). Determinants of perceived ease of use: Integrating control, intrinsic motivation, and emotion into the technology acceptance model. Information systems research, 11(4), 342365.

[69] Venkatesh, V., \& Bala, H. (2008). Technology acceptance model 3 and a research agenda on interventions. Decision sciences, 39(2), 273-315.

[70] Venkatesh, V., Morris, M. G., Davis, G. B., \& Davis, F. D. (2003). User acceptance of information technology: Toward a unified view. MIS quarterly, 425-478.
[71] Venkatesh, V., Thong, J. Y., \& Xu, X. (2012). Consumer acceptance and use of information technology: extending the unified theory of acceptance and use of technology. MIS quarterly, 36(1), 157-178.

[72] Viberg, O. (2015). Design and use of mobile technology in distance language education: Matching learning practices with technologies-inpractice. Repro: Örebro University.

[73] Wang, Y., Rajan, P., Sankar, C. S., \& Raju, P. K. (2017). Let them play: the impact of mechanics and dynamics of a serious game on student perceptions of learning engagement. IEEE Transactions on Learning Technologies, 10(4), 514-525.

[74] Wiebe, E. N., Lamb, A., Hardy, M., \& Sharek, D. (2014). Measuring engagement in video game-based environments: Investigation of the User Engagement Scale. Computers in Human Behavior, 32, 123-132.

[75] Wouters, P., van Oostendorp, H., ter Vrugte, J., Vandercruysse, S., de Jong, T., \& Elen, J. (2017). The effect of surprising events in a serious game on learning mathematics. British journal of educational technology, 48(3), 860-877.

[76] Zhang, Y. (2016). The Impact of Mobile Learning on ESL Listening Comprehension. DEStech Transactions on Social Science, Education and Human Science, (icaem). https://doi.org/10.12783/dtssehs /icaem2016/4290

[77] Zhonggen, Y. (2019). A Meta-Analysis of Use of Serious Games in Education over a Decade. International Journal of Computer Games Technology, 2019, 1-8. https://doi.org/10.1155/2019/4797032

[78] Ishaq, K., Zin, N. A. M., Rosdi, F., Abid, A., \& Farooq, U. (2019), Effectiveness of Literacy \& Numeracy Drive (LND): A Students' Perspective.

[79] Hashim, H., Yunus, M. M., Embi, M. A., \& Ozir, N. A. M. (2017). Mobile-assisted language learning (MALL) for ESL learners: A review of affordances and constraints. Sains Humanika, 9(1-5).

[80] Ishaq, K., Zin, N. A. M., Abid, A., Rosdi, F., \& Ali, Q. (2020). Usefulness of Mobile Assisted Language Learning App. International Journal of Engineering and Advanced Technology (IJEAT), 9(3).

[81] Davis, F. D. (1989). Perceived usefulness, perceived ease of use, and user acceptance of information technology. MIS quarterly, 319-340.

[82] Venkatesh, V., \& Davis, F. D. (2000). A theoretical extension of the technology acceptance model: Four longitudinal field studies. Management science, 46(2), 186-204. 